\title{
Examining the Effects of Entrepreneurial Competencies on Students' Entrepreneurial Intention
}

\author{
Abdullah Al Mamun ${ }^{1^{*}}$ \\ Noorshella Binti Che Nawi1 \\ Anushah A/P Dewiendren² \\ Siti Farhah Fazira Binti Shamsudin² \\ 1 Senior Lecturer, Faculty of Entrepreneurship and Business, Universiti Malaysia Kelantan \\ ${ }^{2}$ Graduate Student, Faculty of Entrepreneurship and Business, Universiti Malaysia Kelantan \\ *Corresponding Author, Email: abdullah.a@umk.edu.my
}

Doi:10.5901/mjss.2016.v7n2p119

\section{Abstract}

Entrepreneurship is regarded as one of the key development initiatives, which leads to employment and economic growth; therefore, reducing poverty and inequality. Besides providing support to existing entrepreneurs, over the recent years, policy makers have focused on entrepreneurial education to cope with graduate unemployment issues and to foster economic growth. The foundation of quality entrepreneurial education depends on our understanding of entrepreneurial competencies and the effects on a student's entrepreneurial intention. This study therefore focuses on examining the effect of key entrepreneurial competencies on a student's entrepreneurial intention. This study adopted a cross-sectional design and a quantitative approach, and collected complete data from 333 students, studying commerce related subjects in Universiti Malaysia Kelantan. Findings of this study revealed that the students' ability to recognize income-generating opportunities, entrepreneurial training and skills, innovativeness, and information-seeking competencies has a significant effect on their entrepreneurial intention. The education policy makers and the higher learning institutions in Malaysia should therefore emphasize on programs and curriculums to improve the students' ability to recognize income-generating opportunities, entrepreneurial training and skills, innovativeness and information-seeking competencies, which are expected to reduce the rate of unemployed graduates and foster the economic development in Malaysia.

Keywords: Entrepreneurship; Intention; Competencies; Students Career Choice

\section{Introduction}

Entrepreneurship is considered one of the key development initiatives for national development as it reduces the unemployment rate, inequality, and poverty. This brings the development and education policy makers together to develop programs and policies in order to reduce graduate unemployment and foster economic development (Fayolle, Gailly, \& Lassas-Clerc, 2006). Universities can be seen as potential sources of future entrepreneurs since the education offered by universities mostly influences the career selection of students (Thurik et al., 2008). The number of entrepreneurial programs and courses adopted by higher learning institutions all over the world is also increasing (Gwynne, 2008). As the focus has shifted towards potential entrepreneurs, it has become more crucial to unfold the roles of entrepreneurial characteristics and competencies, and the way in which they affect entrepreneurial intention among university students.

Entrepreneurship, as defined by Klofsten and Jones-Evans (2000), is the process of exploring new ways of combining resources. Laguador (2013) extended the definition by adding that entrepreneurship is the ability of individuals to perceive the kind of products or services that others need and to deliver them at the right time, at the right place, to the right people, and at the right price. Entrepreneurial activities start with entrepreneurial intention, which is shaped through personality traits and competencies, together with the interaction with the environment. Entrepreneurial intention is commonly formed during a process where an individual passes through different life stages in which he/she becomes aware of opportunities and selects the most preferred choice. According to Krueger et al. (2000), the decision to become an entrepreneur is described as deliberate and conscious. It requires careful and thoughtful planning. Hence, it seems rational to analyze how that decision is taken by studying the intention that leads to the decision making in order to have 
a better understanding of where the ideas to start a business venture come from and how it becomes a reality.

A career as an entrepreneur offers the individual ample opportunities to enjoy independence, reap greater financial payback and gain towards overall economy through a contribution to innovation, job enhancement, and economic development. For developing economies, entrepreneurship works like an engine for economic growth, job creation, and social adjustment (Ahmed, 2010). However, it involves a relatively higher level of investment that is associated with a higher level of risk, as the performance of enterprises depends on the entrepreneurial competencies. Earlier studies listed a number of factors that leads to the decision of starting a business. Ashley-Cotleur, King, and Solomon (2009) argued that a number of individual factors trigger a person's intention to become an entrepreneur. Entrepreneurial competencies are viewed as crucial to business growth and success, and the understanding of the nature and role of such competencies can have significant effects in practice (Mitchelmore \& Rowley, 2010). Entrepreneurial competencies have also been identified as a particular group of competencies that is significant to the practice of successful entrepreneurship (Mitchelmore \& Rowley, 2010). According to Bird (1995), entrepreneurial competencies are the underlying characteristics such as specific knowledge, motives, traits, self-images, social roles, and skills, which result in a venture's birth, survival and growth. In addition, Man et al. (2002) defined entrepreneurial competencies as the overall capability of the entrepreneur to execute a job role successfully. Based on the earlier findings, this study focused on examining how opportunity recognition, training and skill competencies, risk-taking propensity competencies, innovativeness and information-seeking competencies, which expected to affect students' entrepreneurial intention.

\subsection{Study context: Entrepreneurship Development Programs in UMK}

According to Sharrif and Saud (2009), universities have a key role in promoting entrepreneurship since educational institutions are ideally considered as the place that shapes entrepreneurial cultures and aspirations among students while they are studying to survive in today's robust business milieu. University Malaysia Kelantan (UMK) is one of the institutions responsible for providing entrepreneurship programs to students for enhancing the students' entrepreneurship knowledge and skills acquisition. UMK plays an active role in designing entrepreneurship programs for the students. These roles include providing physical facilities and loans for students to start their own business, networking, and entrepreneurship training. UMK provides 12 credits of entrepreneurial courses across the faculties which is a minimum of $10 \%$ of the course content's established knowledge in entrepreneurship education that incorporates real-life experiences, sound entrepreneurial practices displayed which are put into practice as well as case studies of success stories shared by successful entrepreneurs themselves. UMK provides many programs such as the Students in Enterprise Program (SIEP) and the Social Entrepreneurship Program where the students will find themselves participating in a program for economic and community development. This is conducted through a social entrepreneurship subject. Besides that, the approach and style of teaching has been shifted from that of conventional teaching to Student Centered Learning $(\mathrm{SCL})$ by teaching students through case studies, group work, visitation to companies, and presentations from the first year until the fourth year. Moreover, UMK academic staffs have the ability to master the teaching of entrepreneurial education. Academic staffs must ensure they are involved in excellent teaching, quality research and development, publications, commercialization of ideas and research findings, and strong collaboration with the industries and the communities. In addition, UMK is innovative and creative in delivering the entrepreneurial education. There are additional programs that are provided for the students to encourage them to become entrepreneurs such as enterprise Saturday by inviting practitioners to share their experience, business plan competitions, entrepreneurship forums, exhibitions of student-led activities, and student-owned businesses in the campus. Since UMK is a relatively new university, most of the entrepreneurship programs have only been recently introduced and are continuously being upgraded. Therefore, this study focuses on examining the effects of entrepreneurial traits and competencies on students' entrepreneurial intention, which would improve our knowledge and understanding and contribute to the development of effective entrepreneurship development programs.

\section{Literature Review}

Earlier studies used the resource-based view to explain the effect of entrepreneurial competencies on enterprise performance, as resource-based view focused on enterprise resources as the key elements of enterprise performance (Peteraf and Barney, 2003). However, this focused on potential entrepreneurs and intended to measure entrepreneurial intention among business graduates. The theory of planned behavior explains the entrepreneurial intention by means of attitudes, perceived behavioral control, and subjective norms (Ajzen, 1991). As entrepreneurial intention represents the behavioral aspects of entrepreneurs, the association between entrepreneurial competencies and entrepreneurial intention 
can be explained by the theory of planned behavior.

Studies on entrepreneurial competencies have attempted to organize these entrepreneurial competencies into various sub-constructs. For example, Man et al. (2002) identified six competency areas in their work: opportunity, organizing, strategic, relationship, commitment, and conceptual competencies. On the other hand, Priyanto and Sandjojo (2005) divided entrepreneurial competency into four scopes: management skills, industry skills, opportunity skills, and technical skills. However, this study focuses on five types of entrepreneurial traits and competencies, which are opportunity recognition, training and skill competencies, risk-taking propensity competencies, innovativeness, and information-seeking competencies.

\subsection{Opportunity Recognition}

The first component of entrepreneurial traits is opportunity recognition. This category of trait consists of entrepreneurial activities that recognize opportunities, pursue new opportunities vigorously, and develop the opportunities (Li, 2009). Kirzner (1973) defined recognizing opportunities as alertness to changed conditions or to overlooked possibilities. Entrepreneurs are regularly categorized by their capacity to identify opportunities (Bygrave \& Hofer, 1991). Shane and Venkataraman (2000) argued that identifying and exploiting opportunities are focal concepts in entrepreneurship that distinguishes entrepreneurship from management. Meanwhile, Evans and Volery (2001) described the entrepreneur as one who identifies opportunities, combines resources, and produces new services that are the catalyst for the creation of the wealth process. Opportunity recognition, or the chance identification to combine resources in a way that may generate income, is an essential part of entrepreneurship (Gaglio \& Katz, 2001; Shane \& Venkataraman, 2000). It has constantly been considered as a fundamental part of entrepreneurship (Gaglio, 2004). It is also viewed as a personal awareness in realizing new methods and finishing off with new answers after a prior related venture has been well investigated to avoid any risk of failure (Ulhøi, 2005). This is because people need to detect opportunities to be entrepreneurs thus; the opportunity identification skill increases the possibility of a person becoming an entrepreneur (Baron \& Ensley, 2006; Casson \& Wadeson, 2007; Gaglio \& Katz, 2001). Based on the empirical findings reported above, this study argues that a higher level of opportunity recognition traits has a positive effect on entrepreneurial intention among commerce students.

\section{$H_{1}$ : Opportunity recognition traits have a significant positive effect on entrepreneurial intention}

\subsection{Training and Skills}

Another important component of entrepreneurial competencies is training and skill, which represents entrepreneurial 'know-how'. Training controls and directs others to grow new skills or knowledge that will improve their work. On the other hand, skills can be learned and enhanced by participating in programs and have the tendency to change in the experimental period. In other words, training and skill competencies improve problem-solving and decision-making capabilities and enhance interpersonal relationships, cooperation, and management of money. Moreover, training in entrepreneurship benefits the students who become familiar with their local working and business life as well as provides awareness of the challenges that the local community is facing. The training also focuses on conveying knowledge on how to start new businesses and about modernizing existing enterprises. According to Ladzani and Van Vuuren (2002), beneficial training categories might comprise of motivational, business, and entrepreneurial skills training. Training and educational services are mainly significant in developing market economies as entrepreneurs lack basic business skills (Gnyawali \& Fogel, 1994). Skill is also significant to entrepreneurs because it helps in building self-motivation and confidence in their business. In terms of skill, Bird (1995) suggested that entrepreneurial skill contributes to venture performance, thus one should learn the most important entrepreneurial skills and competences, which are needed in running a company including general management skills in business such as strategy skills, planning skills, marketing skills, financial skills, project management skills, and time management skills. In addition, entrepreneurial skills also include creativity, innovation, risk-taking, and the capability to understand successful entrepreneurial role models and opportunity identification. Meanwhile, business skills include the ability to produce business plans, financial, marketing, operational, human resources, legal, communication, and management skills (Ladzani \& Van Vuuren, 2002). Based on the earlier findings, this study argues that a relatively higher level of training and entrepreneurship related skills is expected to have a significant effect on entrepreneurial intention among UMK commerce students.

$\mathrm{H}_{2}$ : Training and skills have a significant positive effect on entrepreneurial intention 


\subsection{Risk-Taking Propensity}

The third component of entrepreneurial traits and competencies is risk-taking propensity. Risk-taking was the earliest identified entrepreneurial characteristic. Risk-taking propensity has always been linked to entrepreneurship (Pascoe, Mortimer, 2014). Risk propensity can be defined as an individual's tendency to take or avoid risks (Tang \& Tang, 2007). Tang and Tang (2007) further argued that risk bearing is a vital element of entrepreneurship. This is because a person is not certain whether the preferred products can be formed, consumers' needs can be met, or profits can be generated before a new product or service is presented. Entrepreneurship would not be the same attractive subject as it is today without risk-taking. Risk-taking propensity could be conceptualized excellently as an individual orientation towards taking chances in any decision-making situation (Landqvist \& Stalhandske, 2011). An effective risk-taking tendency can also be conceptualized as an individual orientation towards taking advantage of any situation to make a decision. However, several earlier studies have demonstrated contrasting results. A study done by Brockhaus (1980) suggested that risktaking propensity might not be a distinctive entrepreneurial characteristic, which infers that general risk-taking does not differentiate entrepreneurs from non-entrepreneurs. Based on the earlier findings, this study argues that risk-taking propensity has a significant effect on entrepreneurial intention.

$\mathrm{H}_{3}$ : Risk-taking propensity has a significant positive effect on entrepreneurial intention

\subsection{Innovativeness}

The next component of entrepreneurial traits is innovativeness, which is embedded in innovative behavior that is demonstrated by individuals to generate new processes, products, or to enhance administration processes (Amo \& Kolvereid, 2005). In other words, an innovative performance can also be described as the ability to produce and exploit ideas to generate and execute new ideas or to enhance old ideas into new dynamic ways when managing business ventures. Santandreu-Mascarell, Garzon, and Knorr (2013) revealed that one way entrepreneurs contribute to economic development is through innovation involving the growth of new products, new processes, new supply sources, new market exploitation, and the development of new ways to organize business. In addition, there is another important feature of an innovator's competence, which is to know whether markets are ready for commercializing their innovative solutions (Elenurm, 2012). Literature on entrepreneurial intention also shows the positive effect of innovativeness on entrepreneurial attitude (Robinson et al., 1991). Studies conducted by Hamidi et al. (2008) and Armstrong and Hird (2009) reported the strong influence of innovativeness on entrepreneurial intention. This study therefore argues that innovativeness has a significant effect on entrepreneurial intention.

\section{$\mathrm{H}_{4}$ : Innovativeness has a significant positive effect on entrepreneurial intention}

\subsection{Information-Seeking Competencies}

The final component of entrepreneurial competencies is the information-seeking competency. Information literacy is the ability to identify when information is needed as well as to detect, assess, and use the needed information excellently (American Library Association, 1989). Information-seeking also refers to the action of getting information to achieve objectives or to resolve problems, which also include executing personal research on how to provide a product or service, and asking for business or technical advice from experts (Vijay \& Ajay, 2011).

Information-seeking competency is closely related to opportunity recognition. In recognizing opportunities of business, individuals seek information. Previous research proposed that individuals might identify opportunities in starting new ventures because they have excellent access to information due to distinguished search behavior or social networks. Once individuals start spending time to seek and assimilate information, there is a great probability that he or she will eventually discover a new business opportunity (Dyer, Gregersen, \& Christensen, 2008). In addition, a study done by Wing Yan Man (2006) found that entrepreneurs who are competent learners are able to seek learning opportunities actively, even if such opportunities may not be freely open to them. Thus, this study argues that information-seeking competencies have a significant effect on students' entrepreneurial intention.

$H_{5}$ : Information-seeking traits have a significant positive effect on entrepreneurial intention

\section{Research Methodology}

This study used a cross sectional design to examine the effects of entrepreneurial traits and competencies on students' entrepreneurial intention. The population definition was based on the assumption that students who have undergone the 
entrepreneurial learning process are expected to have a better understanding of future careers. Students were selected to measure entrepreneurial intention because they have a strong foundation regarding business-related knowledge and they are currently at the critical stage of deciding their future career path. Most of the students in the final stages of their undergraduate life would be looking for a career; it was deemed that the population selected would reflect student intention and inclination. This study selected sample respondents from a list of 2536 students from the Faculty of Entrepreneurship and Business, Universiti Malaysia Kelantan. Self-administered survey questionnaire was used as the research instrument. Complete data was collected from 330 students.

The questionnaire was designed using simple and unbiased wordings, which the respondents can easily understand and provide answers based on their own perception. Questions were adopted from earlier studies with minor modifications where needed. The five-point Likert scale of 1 to 5 points (strongly disagree, disagree, neutral, agree, and strongly agree) was used for the independent and dependent variables. Due to the exploratory nature of this study, together with the relatively low sample size and non-normal data, this study used the variance based structural equation modeling, i.e., partial least squares (PLS) estimation with the primary objective of maximising the explanation of variance in the structural equation model's dependent constructs. The findings of this analysis were reported as recommended by Hair, Ringle, and Sarstedt (2013) for PLS modeling.

\section{Research Finding}

\subsection{Demographic Characteristics}

Complete data was collected from 333 students. As presented in Table 1, among the total of 333 students, 93 of them are male and 240 of them are female. A total of 232 out of 333 students are aged between 21 to 23 years old. Among the students, a relatively higher proportion of them are currently studying 'Islamic banking and finance', and 'hospitality', followed by 'logistics', 'tourism', 'commerce', 'retailing', and 'health entrepreneurship'. As for the parents' occupations, a relatively higher proportion of respondents' fathers are self-employed compared to the respondents' mothers.

Table 1. Respondent's Demographic Characteristics

\begin{tabular}{|c|c|c|c|c|c|}
\hline Category & $\mathrm{n}$ & $\%$ & Category & $\mathrm{n}$ & $\%$ \\
\hline \multicolumn{3}{|l|}{ Course currently pursued } & \multicolumn{3}{|l|}{ Gender } \\
\hline Retailing & 39 & 11.7 & Male & 93 & 27.9 \\
\hline Islamic banking and finance & 69 & 20.7 & Female & 240 & 72.1 \\
\hline Commerce & 41 & 12.3 & Total & 333 & 100.0 \\
\hline Logistic and distributive trade & 56 & 16.8 & & & \\
\hline Hospitality & 63 & 18.9 & \multicolumn{3}{|l|}{ Respondent's Age } \\
\hline Tourism & 43 & 12.9 & Below 21 & 71 & 21.3 \\
\hline Health entrepreneurship & 22 & 6.6 & 21 to 23 & 232 & 69.7 \\
\hline \multirow[t]{2}{*}{ Total } & 333 & 100.0 & 25 to 26 & 30 & 9.0 \\
\hline & & & Total & 333 & 100.0 \\
\hline \multicolumn{6}{|l|}{ Father's Occupation } \\
\hline loyed & 143 & 42.9 & \multicolumn{3}{|l|}{ Mother's Occupation } \\
\hline Self-Employed & 93 & 27.9 & Employed & 96 & 28.4 \\
\hline In Between Jobs & 14 & 4.2 & Self-Employed & 60 & 18 \\
\hline Unemployed & 40 & 12.0 & In Between Jobs & 10 & 3.0 \\
\hline Retired & 43 & 12.9 & Unemployed & 152 & 45.6 \\
\hline \multirow[t]{2}{*}{ Total } & 333 & 100.0 & Retired & 15 & 4.5 \\
\hline & & & Total & 333 & 100.0 \\
\hline
\end{tabular}

\subsection{Reliability measures}

Cronbach's Alpha provides an estimate for the reliability based on the indicators' inter-correlations. The Cronbach's Alpha, as presented in Table 2, for all indicators are more than 0.7; this study considered all items as reliable. Moreover, the composite reliability, which takes into account that the indicators have different loadings for all items, is more than 0.8 , which is higher than 0.7 (Hair, Ringle, \& Sarstedt, 2013), therefore it is considered as reliable. Convergent validity signifies that a set of indicators represents one and the same underlying construct, which can be demonstrated through 
their unidimensionality. The average variance extracted (AVE) value for all items is more than 0.5 , which indicates sufficient convergent validity.

Table 2. Descriptive and reliability measures

\begin{tabular}{ccccccc}
\hline & \multirow{2}{*}{ Number of Items } & \multicolumn{2}{c|}{ Descriptive } & \multicolumn{3}{c}{ Reliability } \\
\cline { 3 - 6 } & & Mean & S. Deviation & CA & Cl & AVE \\
\hline OPR & 4 & 3.85 & 0.5981 & 0.731 & 0.830 & 0.552 \\
TAS & 4 & 3.86 & 0.5446 & 0.708 & 0.821 & 0.536 \\
RTP & 4 & 3.89 & 0.5379 & 0.711 & 0.821 & 0.536 \\
INO & 4 & 3.92 & 0.5595 & 0.722 & 0.827 & 0.546 \\
ISE & 4 & 4.03 & 0.5053 & 0.711 & 0.820 & 0.533 \\
EIT & 4 & 3.88 & 0.5791 & 0.737 & 0.835 & 0.562 \\
\hline
\end{tabular}

OPR: Opportunity Recognition; TAS: Training and Skill; RTP: Risk-Taking Propensity; INO: Innovativeness; ISE: Information-seeking; ETI: Entrepreneurial Intention; CA: Cronbach's Alpha; Cl: Composite Reliability; AVE: Average Variance Extracted

Table 3. Outer model loading and cross loading

\begin{tabular}{|c|c|c|c|c|c|c|}
\hline & Opportunity Recognition & Training and Skill & Risk-Taking Propensity & Innovativeness & Information-Seeking & Entrepreneurial Intention \\
\hline$\overline{\text { OPR - Item } 1}$ & 0.623 & 0.320 & 0.260 & 0.265 & 0.289 & 0.206 \\
\hline OPR - Item 2 & 0.783 & 0.416 & 0.335 & 0.335 & 0.374 & 0.362 \\
\hline OPR - Item 3 & 0.781 & 0.406 & 0.273 & 0.267 & 0.243 & 0.348 \\
\hline OPR - Item 4 & 0.771 & 0.440 & 0.351 & 0.365 & 0.378 & 0.316 \\
\hline TAS - Item 1 & 0.423 & 0.621 & 0.331 & 0.455 & 0.441 & 0.334 \\
\hline TAS - Item 2 & 0.419 & 0.819 & 0.374 & 0.382 & 0.396 & 0.449 \\
\hline TAS - Item 3 & 0.405 & 0.727 & 0.300 & 0.337 & 0.283 & 0.329 \\
\hline TAS - Item 4 & 0.323 & 0.748 & 0.327 & 0.386 & 0.358 & 0.346 \\
\hline RTP - Item 1 & 0.246 & 0.317 & 0.633 & 0.270 & 0.337 & 0.250 \\
\hline RTP - Item 2 & 0.299 & 0.393 & 0.735 & 0.432 & 0.329 & 0.289 \\
\hline RTP - Item 3 & 0.315 & 0.332 & 0.811 & 0.356 & 0.415 & 0.377 \\
\hline RTP - Item 4 & 0.341 & 0.309 & 0.738 & 0.415 & 0.397 & 0.294 \\
\hline INO - Item 1 & 0.293 & 0.383 & 0.415 & 0.751 & 0.401 & 0.323 \\
\hline INO - Item 2 & 0.311 & 0.348 & 0.402 & 0.749 & 0.391 & 0.346 \\
\hline INO - Item 3 & 0.332 & 0.422 & 0.353 & 0.780 & 0.472 & 0.407 \\
\hline INO - Item 4 & 0.283 & 0.401 & 0.321 & 0.670 & 0.356 & 0.370 \\
\hline ISE - Item 1 & 0.383 & 0.426 & 0.362 & 0.385 & 0.670 & 0.253 \\
\hline ISE - Item 2 & 0.230 & 0.301 & 0.287 & 0.340 & 0.698 & 0.335 \\
\hline ISE - Item 3 & 0.341 & 0.424 & 0.434 & 0.447 & 0.763 & 0.397 \\
\hline ISE - Item 4 & 0.322 & 0.342 & 0.391 & 0.435 & 0.783 & 0.385 \\
\hline ETI - Item 1 & 0.399 & 0.382 & 0.366 & 0.461 & 0.380 & 0.799 \\
\hline ETI - Item 2 & 0.318 & 0.447 & 0.284 & 0.407 & 0.390 & 0.833 \\
\hline ETI - Item 3 & 0.327 & 0.349 & 0.244 & 0.316 & 0.381 & 0.681 \\
\hline ETI - Item 4 & 0.208 & 0.325 & 0.375 & 0.266 & 0.274 & 0.671 \\
\hline
\end{tabular}

Indicators are assumed to be reliable if the absolute standardized outer (component) loadings are higher than 0.7. As noted in Table 3, most of the items used to measure 'opportunity recognition', 'training and skill', 'risk-taking propensity', 'innovativeness', 'information-seeking', and 'entrepreneurial intention' are more than 0.7 , and therefore assumed to be reliable. Cross-loadings check was carried out for discriminant validity. If an indicator has a higher correlation with another latent variable compared to its respective latent variable, the appropriateness of the model should be reconsidered. As noted in Table 3, cross-loading values are far below the outer loadings, which suggest good discriminant validity.

Table 4. Discriminant validity

\begin{tabular}{|c|c|c|c|c|c|c|}
\hline & $\begin{array}{l}\text { Opportunity } \\
\text { Recognition }\end{array}$ & $\begin{array}{c}\text { Training and } \\
\text { Skill }\end{array}$ & $\begin{array}{l}\text { Risk-Taking } \\
\text { Propensity }\end{array}$ & Innovativeness & $\begin{array}{l}\text { Information- } \\
\text { Seeking }\end{array}$ & $\begin{array}{c}\text { Entrepreneurial } \\
\text { Intention }\end{array}$ \\
\hline \multicolumn{7}{|c|}{ Fornell-Larcker Criterion } \\
\hline OPR & 0.743 & & & & & \\
\hline
\end{tabular}




\begin{tabular}{|c|c|c|c|c|c|c|}
\hline TAS & 0.536 & 0.732 & & & & \\
\hline RTP & 0.411 & 0.457 & 0.732 & & & \\
\hline INO & 0.414 & 0.529 & 0.502 & 0.739 & & \\
\hline ISE & 0.430 & 0.505 & 0.507 & 0.552 & 0.730 & \\
\hline EIT & 0.425 & 0.504 & 0.419 & 0.494 & 0.479 & 0.749 \\
\hline \multicolumn{7}{|c|}{ Heterotrait-Monotrait Ratio (HTMT) } \\
\hline \multicolumn{7}{|l|}{ OPR } \\
\hline TAS & 0.743 & & & & & \\
\hline RTP & 0.567 & 0.647 & & & & \\
\hline INO & 0.568 & 0.743 & 0.706 & & & \\
\hline ISE & 0.607 & 0.720 & 0.707 & 0.762 & & \\
\hline EIT & 0.555 & 0.688 & 0.578 & 0.659 & 0.644 & \\
\hline
\end{tabular}

OPR: Opportunity Recognition; TAS: Training and Skill; RTP: Risk-Taking Propensity; INO: Innovativeness; ISE: Information-seeking; ETI: Entrepreneurial Intention

Fornell-Larcker criterion assesses the discriminant validity at the construct level. As noted by Hair, Ringle, and Sarstedt (2013), the AVE of each latent construct should be higher than the construct's highest squared correlation with any other latent construct. The Fornell-Larcker criterion in Table 4 is largely unable to detect a lack of discriminant validity. Furthermore, the Heterotrait-Monotrait Ratio (HTMT) is an estimate of the correlation between constructs, which parallels the disattenuated construct score creation. Using a value of 0.9 as the threshold, this study concluded that there is no evidence of a lack of discriminant validity.

\subsection{Path Coefficients}

Verifying the reliability and validity of the outer model allowed an evaluation of the inner path model estimates. The coefficient of determination $\left(r^{2}\right)$ of the endogenous latent variables, i.e., student's entrepreneurial intention, as shown in Table 5 is 0.372 , and therefore considered moderate. This moderate $r^{2}$ value is considered as acceptable because this study is not designed to identify which key factors affect the students' entrepreneurial intention; rather, it attempts to identify how entrepreneurial traits and competencies affect students' 'entrepreneurial intention'.

Table 5. Path Coefficients

\begin{tabular}{lccccccc}
\hline & Path Coefficient & $\mathrm{t}$ & $p$ & $r^{2}$ & Effect Size & $\mathrm{Q}^{2}$ & $q^{2}$ \\
\hline OPR $=>$ ETI & 0.124 & 1.964 & 0.025 & & 0.016 & & 0.006 \\
TAS $=>$ ETI & 0.210 & 3.007 & 0.001 & & 0.039 & & 0.015 \\
RTP $=>$ ETI & 0.091 & 1.409 & 0.080 & 0.372 & 0.008 & 0.194 & - \\
INO $=>$ ETI & 0.194 & 3.080 & 0.001 & & 0.034 & & 0.014 \\
ISE $=>$ ETI & 0.167 & 2.731 & 0.003 & & 0.026 & & 0.009 \\
\hline
\end{tabular}

OPR: Opportunity Recognition; TAS: Training and Skill; RTP: Risk-Taking Propensity; INO: Innovativeness; ISE: Information-seeking; ETI: Entrepreneurial Intention

The path coefficient between student's abilities to recognize income-generating opportunities, training and skills, innovativeness, and information-seeking behavior shows a positive significant (at $5 \%$ level of significance) effect on their entrepreneurial intention. Although risk-taking propensity has a positive effect on entrepreneurial intention, the effect is not statistically significant (at $5 \%$ level of significance). The effect size (f2) is calculated as the increase in $\mathrm{r} 2$ relative to the proportion of variance of the endogenous latent variable that remains unexplained. As shown in Table 5, all significant exogenous latent variables have a small effect size, which indicates that besides entrepreneurial traits and competencies, there are other key factors that affect students' entrepreneurial intention.

The predominant measure of predictive relevance is Stone-Geisser's Q2, which postulates that the model must be able to provide a prediction of the endogenous latent variable's indicators (Hensler, Ringle, \& Sinkovice, 2009). The Q2 value of the endogenous latent constructs, i.e., student's entrepreneurial intention is more than 0 , which is indicative of predictive relevance. Moreover, the q2 value measures the predictive relevance for exogenous latent variables. As noted in Table 5, the $q 2$ values reveal a small predictive relevance $(q 2<0.02)$ for recognizing income-generating opportunities, training and skills, innovativeness, and information-seeking behavior on student's entrepreneurial intention. 


\section{Conclusion}

By identifying the factors such as opportunity recognition competencies, training and skill, risk-taking propensity, innovativeness, and information-seeking competencies regarding a student's entrepreneurial intention, this study makes several important contributions. First, the study found that opportunity recognition competencies have a significant effect on entrepreneurial intention. In other words, students who are able to recognize the opportunities in entrepreneurship activities are more likely to be an entrepreneur. In fact, Gaglio (2004) believed that this factor is constantly one of the fundamentals of entrepreneurship. Secondly, the result also reveals that training and skills have a significant positive effect on entrepreneurial intention. It cannot be denied that students who have been trained and exposed to entrepreneurship programs will develop more knowledge on entrepreneurship. Furthermore, through the trainings that they have attended, the more skills they would acquire. Students who have necessary skills coupled with adequate resources will choose entrepreneurship as their career. Even though risk-taking propensity is always linked to entrepreneurship (Pascor \& Mortimer, 2014), the finding in this study is contradictory. However, innovativeness is found to be one of the factors that affect students' entrepreneurial intentions. In fact, innovativeness is one of the entrepreneurial mindsets. Entrepreneurial innovativeness will add value to economic development; for instance, in developing new products, identifying new processes as well as exploiting new markets. Lastly, information-seeking competencies are found to be a factor affecting students' career choice as an entrepreneur. As the students have been categorized as 'Gen $Y$ ' that loves to seek and gather information through the Internet, having more knowledge and information about the business, will lead them to be involved in a self-employed business. This is true for individuals who are able to identify opportunities because they have good access to information (Dyer, Gregerson, \& Christensen, 2008). As per the limitations, this study measured entrepreneurial intention among the business students in Universiti Malaysia Kelantan, therefore these findings may not translate to all business students in Malaysia. Development policymakers should therefore focus on incorporating programs and curriculums to improve students' abilities to recognize incomegenerating opportunities, training and skills, innovativeness, and information-seeking behavior, which will ultimately improve the students' intention to become an entrepreneur and foster national development through reducing poverty and unemployment rates among fresh graduates in Malaysia.

\section{References}

Ahmed, I., Nawaz, M.M., and Ahmad, Z. (2010) Determinants of students entrepreneurial career intentions: Evidence from business graduates. European Journal of Social Science. 15(2); 14-22

Ajzen, I. (1991), The theory of planned behaviour, Organizational Behaviour and Human Decision Processes, 50(2): 179-211.

Armstrong, S.J. and Hird, A. (2009), Cognitive style and entrepreneurial drive of new and mature business owner-managers, Journal of Business and Psychology, 24: 419-30.

Ashley-Cotleur, C, King, S. and Solomon, G. (2009). Parental and gender influences on entrepreneurial intentions, motivations and attitudes. [Online] Available: http://usasbe.org/knowledge/proceedings/proceedings Docs/USASBE 2003 proceedings-12pdf. (April 22, 2014).

American Library Association. (1989) Presidential Committee on Information Literacy: Final Report, January 10, http://www.ala.org/acrl/ publications/whitepapers/presidential (Accessed August 22, 2015).

Amo, B. W., \& Kolvereid, L. (2005). Organizational strategy, individual personality and innovation behavior. Journal of Enterprising Culture, 13(01), 7-19.

Bird, B. (1995). Towards a theory of entrepreneurial competency. Advances in entrepreneurship, firm emergence and growth, 2(1), 5172.

Baron, R. A., \& Ensley, M. D. (2006). Opportunity recognition as the detection of meaningful patterns: Evidence from comparisons of novice and experienced entrepreneurs. Management science, 52(9), 1331-1344.

Brockhaus, R. H. (1980). Risk taking propensity of entrepreneurs. Academy of management Journal, 23(3), 509-520.

Bygrave, W., \& Hofer, C. (1991) Theorizing about Entrepreneurship. Entrepreneurship Theory \& Practice, 15: 7-25.

Casson, M., \& Wadeson, N. (2007). The discovery of opportunities: Extending the economic theory of the entrepreneur. Small Business Economics, 28(4), 285-300.

Dyer, J. H., Gregersen, H. B., \& Christensen, C. (2008). Entrepreneur behaviors, opportunity recognition, and the origins of innovative ventures.Strategic Entrepreneurship Journal, 2(4), 317-338.

Elenurm, T. (2012). Entrepreneurial orientations of business students and entrepreneurs. Baltic Journal of Management, 7(2), 217-231.

Evans, D., \& Volery, T. (2001). Online business development services for entrepreneurs: an exploratory study. Entrepreneurship \& Regional Development, 13(4), 333-350.

Fayolle, A., Gailly, B. t., \& Lassas-Clerc, N. (2006). Assessing the impact of entrepreneurship education programmes: a new methodology. Journal of European Industrial Training, 30(8/9): 701-720.

Gaglio, C. M. (2004). The Role of Mental Simulations and Counterfactual Thinking in the Opportunity Identification 
Process*. Entrepreneurship Theory and Practice, 28(6), 533-552.

Gaglio, C. M., \& Katz, J. A. (2001). The psychological basis of opportunity identification: Entrepreneurial alertness. Small business economics, 16(2), 95-111.

Gnyawali, D. R., \& Fogel, D. S. (1994). Environments for entrepreneurship development: key dimensions and research implications. Entrepreneurship Theory and Practice, 18, $43-43$.

Gwynne, P. (2008). More Schools Teaching Entrepreneurship. Research Technology Management, 51(2): 6-8.

Hair J. F. Jr., Ringle, C. M. and Sarstedt, M. (2013) Partial Least Squares Structural Equation Modeling: Rigorous Applications, Better Results and Higher Acceptance, Long Range Planning 46: 1-12

Hamidi, D., Wennberg, K. and Berglund, H. (2008), Creativity in entrepreneurship education, Journal of Small Business and Enterprise Development, Vol. 15 No. 2, pp. 304-20.

Kirzner, I. M. (1973) Competition \& Entrepreneurship. Chicago: University of Chicago Press.

Krueger, N. F., Reilly, M. D., \& Carsrud, A. L. (2000). Competing models of entrepreneurial intentions. Journal of business venturing, 15(5), 411-432.

Klofsten M. and Jones-Evans, D. (2000). Comparing Academic Entrepreneurship in Europe - The Case of Sweden and Ireland, Small Business Economics, 14(4), 299-309.

Ladzani, W. M., \& Van Vuuren, J. J. (2002). Entrepreneurship training for emerging SMEs in South Africa. Journal of Small Business Management,40(2), 154-161.

Laguador, J. M. (2013) A Correlation Study of Personal Entrepreneurial Competency and the Academic Performance in Operations Management of Business Administration Students, International Journal of Academic Research in Business and Social Sciences, $3(5), 61-70$.

Landqvist, H., \& Stålhandske, P. (2011). Risk propensity of entrepreneurs-A study of underlying factors in background and personality in comparison with managers. Management \& Organization reports No: 11: 64. Available from: http://hdl.handle.net/2077/26609

$\mathrm{Li}, \mathrm{X}$. (2009). Entrepreneurial competencies as an entrepreneurial distinctive: An examination of the competency approach in defining entrepreneurs. Dissertation. Singapore Management University

Man, T. W., Lau, T., \& Chan, K. F. (2002). The competitiveness of small and medium enterprises: A conceptualization with focus on entrepreneurial competencies. Journal of Business Venturing, 17(2), 123-142.

Mitchelmore, S., \& Rowley, J. (2010). Entrepreneurial competencies: a literature review and development agenda. International journal of entrepreneurial Behavior \& Research, 16(2), 92-111.

Sharrif, M. N. M. and Saud, M. B. (2009). An attitude approach to the prediction of entrepreneurship on students at institution of higher learning in Malaysia. International Journal of Business Management, 4(4), 129-135.

Pascor, K., \& Mortimer, K. (2014). Identifying entrepreneurs through risk taking behaviour: illegal downloading. Journal of Research in Marketing and Entrepreneurship, 16(2), 183-199.

Peteraf, M. and Barney, J. (2003) Unraveling The Resource-Based Tangle, Managerial and Decision Economics, 24(4), 309-323.

Priyanto, S. H., \& Sandjojo, I. (2005). Relationship between entrepreneurial learning, entrepreneurial competencies and venture success: empirical study on SMEs. International Journal of Entrepreneurship and Innovation Management, 5(5-6), 454-468.

Robinson, P.B., Stimpson, D.V., Huefner, J.C. and Hunt, H.K. (1991), An attitude approach to the prediction of entrepreneurship, Entrepreneurship Theory and Practice, 15: 13-31.

Santandreu-Mascarell, C., Garzon, D., \& Knorr, H. (2013). Entrepreneurial and innovative competences, are they the same?. Management Decision, 51(5), 1084-1095.

Shane, S., \& Venkataraman, S. (2000). The promise of entrepreneurship as a field of research. Academy of management review, 25(1), 217-226.

Tang, J., \& Tang, Z. (2007). The relationship of achievement motivation and risk-taking propensity to new venture performance: a test of the moderating effect of entrepreneurial munificence. International Journal of Entrepreneurship and Small Business, 4(4), 450472.

Thurik, A. R., Carree, M. A., van Stel, A., \& Audretsch, D. B. (2008). Does self- employment reduce unemployment? Journal of Business Venturing, 23(6): 673-686.

Ulhøi, J. P. (2005). The social dimensions of entrepreneurship. Technovation, 25(8), 939-946

Vijay, L., \& Ajay, V. K. (2011). Entrepreneurial Competency in SME? S.Bonfring International Journal of Industrial Engineering and Management Science, 1: 5-10.

Wing Yan Man, T. (2006). Exploring the behavioural patterns of entrepreneurial learning: A competency approach. Education +Training, 48(5), 309-321. 